\title{
Environmental Epidemiology of Essential Tremor
}

\author{
Elan D. Louis \\ GH Sergievsky Center, Department of Neurology, Taub Institute for Research on Alzheimer's Disease and the \\ Aging Brain, College of Physicians and Surgeons, and Department of Epidemiology, Mailman School of \\ Public Health, Columbia University, New York, N.Y., USA
}

\section{Key Words}

Essential tremor - Environmental epidemiology • Etiology •

Toxin $\cdot$ Harmane $\cdot$ Lead $\cdot$ Pesticides

\begin{abstract}
Background: Essential tremor (ET) is one of the most common neurological disorders. Despite this, the disease mechanisms and etiology are not well understood. While susceptibility genotypes undoubtedly underlie many ET cases, no ET genes have been identified thus far. As with many other progressive, degenerative neurological disorders, it is likely that environmental factors contribute to the etiology of ET. Environmental epidemiology is the study in specific populations or communities of the effect on human health of physical, biologic and chemical factors in the external environment. The purpose of this article is to review current knowledge with regards to the environmental epidemiology of ET. Results: As will be discussed, a series of preliminary casecontrol studies in recent years has begun to explore several candidate toxins/exposures, including harmane (1-methyl$9 \mathrm{H}$-pyrido[3,4-b]indole), lead and agricultural exposures/ pesticides. Conclusions: While several initial results are promising, as will be discussed, additional studies are needed to more definitively establish whether these exposures are associated with ET and if they are of etiological importance.

Copyright $\odot 2008$ S. Karger AG, Base
\end{abstract}

\section{Introduction to Essential Tremor as a Clinical Entity}

Essential tremor (ET) is a chronic, progressive, degenerative brain disease whose most recognizable feature is a $4-$ to $12-\mathrm{Hz}$ kinetic tremor (that is, tremor occurring during volitional movement) of the arms [1]. The tremor may range in severity from mild and functionally unimportant to severe and disabling [2-6]. Aside from arm tremor, head and voice tremors may occur as well $[1,7]$. The clinical features can include a number of other types of tremor, other motor manifestations and nonmotor features. In terms of other types of tremor, many patients also have intention tremor (that is, tremor while approaching a target) and rest tremor occurs in some as well [8-10]. Other motor manifestations have been documented repeatedly. Thus, changes in tandem gait and balance can occur in some ET patients; this gait has been described as ataxic [11, 12]. ET patients with intention tremor have other cerebellar signs such as disdiadochokinesia [13]. Mild oculomotor abnormalities have been documented in ET as well [14]. The presence of a variety of nonmotor features, including specific personality traits $[15,16]$, anxiety [17], depressive symptoms [4, 18-20] and social phobia [21], is gaining wider recognition [22, 23]. Mild cognitive changes (especially executive dysfunction) have been documented in 6 studies [24-29] and increased odds and risk of dementia in $2[30,31]$. Hence, the view of ET that is emerging from clinical studies is that this heterogeneous condition is probably a family of dis-

Dr. Elan Louis

Unit 198, Neurological Institute

710 West 168 th Street

New York, NY 10032 (USA)

Tel. +1 212305 9194, Fax +1 212305 1304, E-Mail EDL2@columbia.edu 
eases whose central defining feature is action tremor of the hands but in which there is considerable clinical heterogeneity $[1,7,32]$.

\section{Epidemiology of ET}

There have been more than 20 studies of the prevalence of ET [33, 34]. Estimates of the crude prevalence of this disorder have varied considerably from study to study, with a number of methodological considerations (for example, use of screening questionnaires in order to select participants for tremor examinations) contributing greatly to this variability. However, in a population-based study in Turkey, in which all individuals were examined by a study neurologist, the prevalence of ET was $4.0 \%$ among individuals aged 40 years and older and $6.3 \%$ among individuals $\geq 60$ years of age [33]. In another population-based study in Finland that used a similar methodology [35], the prevalence was 5.6\% in individuals aged 40 years and older and $9.0 \%$ among individuals $\geq 60$ years of age. Although an age-associated increase in prevalence is a consistent finding across studies [34], and prevalence is highest after the sixth decade $[33,34]$, the disorder can on occasion begin in childhood [36, 37], with many of these young-onset cases being familial [3, 38,39 ]. While prevalence appears to be similar in men and women, it has been reported to be marginally higher in Caucasians than African-Americans [40-42].

Two studies have provided estimates of the incidence of ET. In one study [43], which used a records linkage system to capture all health encounters with individuals with ET, the age- and sex-adjusted incidence was 23.7 per 100,000 White US population. Another study [44], which sampled ET cases directly from the population in the Madrid region, reported an incidence (age $\geq 65$ years) of 616 per 100,000, which was substantially higher than that of the prior study.

Despite the fact that it is a progressive disorder [4547], there are few longitudinal data in patients with ET. In one study [48], 44 patients were followed prospectively for 4 years and accelerometric data demonstrated an approximately $7 \%$ increase in arm tremor amplitude per year, while in another clinical study, an approximately $12 \%$ annual change was reported in clinical tremor ratings [49]. These studies confirm the clinical anecdotal sense that the action tremor of ET worsens over time.

A wealth of clinical data centers on the apparent links between ET and Parkinson's disease (PD) [50-56]. The development of PD has often been described in ET pa- tients [50, 56, 57]. In recent studies, ET patients were 2-4 times more likely to develop PD (that is, ET plus PD) when compared to persons without ET $[57,58]$. ET-like action tremor is more common in PD families than control families [52], further supporting the links between ET and PD, and postmortem studies have now shown that a subset of ET patients has brainstem (mainly in the locus ceruleus) Lewy bodies [59-61].

Mild cognitive changes (especially executive dysfunction) have been documented in 6 studies of ET, several of which had a case-control design [24-29]. One study further showed an increased odds of prevalent dementia and then an increased risk of incident dementia in older-onset ET cases when compared with age-matched controls $[30,31]$.

Studies of mortality are conflicting. While the traditional belief had been that ET was not associated with mortality, there were few data and these data were retrospective [43]. Recent data from a prospective, populationbased study in Spain, showed a $45 \%$ increased risk of mortality in ET, suggesting that the disease may be associated both with increased morbidity and mortality [62].

A number of factors may influence the clinical expression of ET. First, there seems to be an association between age of onset and rate of clinical progression, with olderonset cases having a faster rate of progression [46]. Furthermore, the odds of developing head tremor are markedly higher in women with ET than men with ET [6365].

\section{Underlying Disease Mechanisms}

It is important to consider the underlying pathological anatomy and mechanistic basis of a disease when investigating how and where a putative etiological agent like a toxin enters the brain and then how it produces pathogenic effects. The underlying anatomic pathology of ET has been elusive, although recent postmortem studies have begun to reveal some of the basic underlying degenerative brain changes in patients with this disease. These studies demonstrate 2 different pathologically defined subgroups of ET patients: the majority has degenerative changes [Purkinje cell loss and torpedoes (swellings of the Purkinje cell axon)] in the cerebellum (cerebellar ET), while a smaller number has brainstem Lewy bodies (mainly in the locus ceruleus) with a relatively preserved cerebellum (Lewy body variant of ET) $[59,66,67]$. The presence of Lewy bodies in some ET cases is intriguing 
and, as noted above, may explain the apparent clinical links between ET and PD. From an epidemiological perspective, this raises the possibility that the same set of environmental risk factors might trigger both diseases.

\section{Etiology of ET}

ET is often considered to be largely a genetic disorder [68-74]. There are numerous published examples of families in which the proband and multiple relatives have ET $[68,70-72,74-79]$ and in which the pattern of inheritance is most consistent with an autosomal dominant model. In 1997, linkage was demonstrated to a region on chromosome 2p22-25 in several American families [70] and, in that same year, to chromosome $3 \mathrm{q} 13$ in 16 Icelandic families [74]. Since then, one other study has demonstrated linkage to a region on chromosome 6p23 in several North American families [73]. Other studies have failed to demonstrate linkage to these 3 regions, indicating further genetic heterogeneity $[69,72,80,81]$. Studies have not progressed further and no ET genes have been identified so far $[69,70,73,74]$. A number of studies have also explored the role of genetic polymorphisms in ET [77, 82-90], with single reports of associations between ET and polymorphisms in the following genes: glutathione-S-transferase P1 (involved in metabolism of carcinogens) [84], $\delta$-amino-levulinic acid dehydrogenase (involved in lead kinetics) [86], methylenetetrahydrofolate reductase (involved in folate- and vitamin $\mathrm{B}_{12}$-dependent homocysteine metabolism) [83] and CYP2C19 (possibly related to primidone metabolism) [85].

Although widely considered to have a large genetic component, it is likely that environmental factors contribute to the etiology of ET as well. First, it is commonly stated in the literature that $50 \%$ or more of ET cases have a genetic basis, although some estimates are as low as $17 \%$ [91]. In the only familial aggregation study of ET [92], $55 \%$ of ET cases had no affected first- or second-degree relatives, despite examination of 4.5 relatives per case, on average. This was consistent with data from other series, among whom the majority $(>50 \%)$ of ET cases do not report affected relatives [20,91, 93-97]. Second, in twin studies $[98,99]$ concordance in monozygotic twins was $<100 \%$ (that is, it was $60 \%$ in one study and $63 \%$ in another). Third, the existence of intrafamilial differences in age of onset and severity of tremor $[100,101]$ also suggests that environmental (or perhaps other genetic) factors may be serving as modifiers of an underlying susceptibility genotype. Fourth, temporal trends in disease inci- dence can support the notion that environmental factors may be contributing to the etiology of ET. A temporal trend in the annual incidence of ET was reported in Rochester, Minnesota [43], where the annual age-adjusted incidence per 100,000 rose from 5.8 in the period from 1935 to 1949 , to 15.8 in the period from 1950 to 1964 and 23.5 from 1965 to 1975 . These data, however, should be approached with caution as this trend could also be the result of increased recognition and diagnosis of the disorder rather than a true rise in disease incidence.

Environmental factors are also thought to play a substantial role in other neurological disorders (PD, Alzheimer's disease, amyotrophic lateral sclerosis) [102-113], so that it is not inconceivable that they could play a role in ET. Using the commonly cited value of $50 \%$ for the percentage of cases that occur on a familial basis [91, 114], and given its population prevalence of $4.0 \%$ after age 39 years [33], this then suggests that approximately $2.0 \%$ of the population aged $\geq 40$ years has a nonfamilial form of ET [33]. Despite the apparent extent of the problem, the environmental correlates for this tremor are just beginning to be explored.

\section{Possible Environmental Toxins in ET}

\section{Harmane (1-methyl-9H-pyrido[3,4-b]indole)}

In the selection of possible toxic causes of ET for investigation, the $\beta$-carboline alkaloids are a reasonable choice. They are a group of naturally occurring chemicals that include harmane, norharman, harmine, harmaline and others [115-117]. $\beta$-Carboline alkaloids are a type of heterocyclic amine; structurally, they are comprised of a combination of 5- and 6-ringed (that is, cyclic) carbon structures, which contain an amine group [118]. There is a structural similarity with the neurotoxin 1-methyl-4phenyl-1,2,3,6-tetrahydropyridine (MPTP), which forms the basis for one of the main toxin-induced animal models for PD $[119,120]$. Like MPTP, $\beta$-carboline alkaloids are highly neurotoxic, and it has been known for approximately 100 years that administration of $\beta$-carboline alkaloids to a wide variety of laboratory animals produces an intense and generalized action tremor resembling ET [121]. $\beta$-Carboline alkaloid administration is currently the main animal model for ET and it has been proposed that new pharmacotherapies be tested using exposed animals [122-126]. The $\beta$-carboline alkaloid tremor shares many features with ET, including its principal clinical features (such as tremor frequency), drug response characteristics (responsive to benzodiazepines, ethanol and 
barbiturates) [126-131] and underlying brain changes (changes in the cerebellum, including Purkinje cell loss, have now been documented in ET [67, 132-137]; similarly, $\beta$-carboline alkaloids produce toxic damage with significant loss of cerebellar Purkinje cells) $[121,126,127$, 138-141]. Among human volunteers exposed to intravenously administered harmine, neurological effects include an acute, coarse tremor [142, 143].

Harmane (1-methyl-9H-pyrido[3,4-b]indole) is among the more potent tremor-producing $\beta$-carboline alkaloids [115]. Harmane itself is also very lipid soluble [116] and broadly distributed within the rat brain [144-146]. Brain concentrations are several fold higher than those in the blood [116, 145].

While $\beta$-carboline alkaloids are produced endogenously $[147,148]$, one study estimated that dietary sources were 50 times greater than these endogenous sources [149]. $\beta$-Carboline alkaloids are found in particularly high nanogram/gram concentrations in muscle foods (beef, chicken and pork) and cooking leads to furthermore increased concentrations [150-153]. Indeed, the formation of $\beta$-carboline alkaloids in cooked meat is a function of cooking temperature and time, with $\beta$-carboline alkaloid concentrations increasing most rapidly with time at higher temperatures [154, 155]. Pan frying and grill/barbequing produce the highest concentrations of $\beta$-carboline alkaloids. In addition to their high concentration in meat, $\beta$-carboline alkaloids are also present in varying concentrations in plant-derived foods/substances, including coffee, ethanol and tobacco [156].

In 2002, Louis et al. [157] demonstrated that blood harmane concentration was elevated in 100 ET patients at the Neurological Institute of New York compared to 100 matched control subjects (median blood harmane: $5.21 \mathrm{~g}^{-10} / \mathrm{ml}$ in cases vs. $2.28 \mathrm{~g}^{-10} / \mathrm{ml}$ in controls, $\mathrm{p}=$ $0.005)$. In analyses that adjusted for age and other confounders, there was a robust association between $\log$ blood harmane concentration and ET diagnosis: odds ratio $(\mathrm{OR})_{\mathrm{ET} \text { vs. control }}=1.80,95 \%$ confidence interval $(\mathrm{CI})=$ $1.10-2.93, \mathrm{p}=0.02$ (that is, each $1 \mathrm{~g}^{-10} / \mathrm{ml}$ increase in blood harmane concentration was associated with an $80 \%$ increased odds of ET) [157]. With continued enrollment from the years 2002-2007, a larger replicate sample of $150 \mathrm{ET}$ cases and 135 matched controls was assembled [158]. While overall concentrations were lower in this sample, the case-control difference persisted (median blood harmane: $2.61 \mathrm{~g}^{-10} / \mathrm{ml}$ in cases vs. $1.82 \mathrm{~g}^{-10} / \mathrm{ml}$ in controls, $\mathrm{p}=0.016$ ) [158].

Using magnetic resonance spectroscopic imaging, Louis et al. [159] also demonstrated a strong inverse cor- relation between cerebellar $\mathrm{N}$-acetyl aspartate to creatine ratio (a marker of neuronal damage) and blood harmane concentrations ( $p=0.009$, adjusting for age and gender) in a small study of 12 ET cases. This correlation was not found in other brain regions (such as thalamus and basal ganglia) or with other neurotoxins (such as lead) [159]. These findings suggest that increased blood harmane concentration could be associated with greater cerebellar neuronal damage, consistent with the animal study data that harmane and other $\beta$-carboline alkaloids produce cerebellar damage [121, 126, 127, 138-141]. Studies of human postmortem tissue are needed to further test this association.

As noted above, harmane is found in high concentrations in cooked meats. In an initial study in 2005, Louis et al. [160] compared animal protein consumption in 106 ET cases versus 161 controls. Total daily animal protein consumption was similar in cases and controls (50.2 \pm 19.6 vs. $49.4 \pm 19.1 \mathrm{~g} /$ day, $\mathrm{p}=0.74)$. However, the study used a standardized food frequency questionnaire [161]. In a follow-up study [162], a more detailed meat consumption questionnaire was used. In that study, total meat consumption was greater in men with ET versus men without ET $(135.3 \pm 71.1$ vs. $110.6 \pm 80.4$ g/day, $\mathrm{p}=0.03$ ) but not in women with versus without ET (80.6 \pm 50.0 vs. $79.3 \pm 51.0 \mathrm{~g} / \mathrm{day}, \mathrm{p}=0.76$ ). Male ET cases had a higher odds of being in the highest versus lowest quartile of current meat consumption than did male controls (unadjusted $\mathrm{OR}=9.29,95 \% \mathrm{CI}=2.29-37.64, \mathrm{p}=0.002$; adjusted $\mathrm{OR}=21.36,95 \% \mathrm{CI}=3.52-129.51, \mathrm{p}=0.001$ ). That study provided preliminary evidence of a dietary difference between males with ET versus males without ET [162], raising the question whether this possible dietary difference, through harmane consumption, could be linked with ET.

The study of harmane and its association with ET has been intriguing, yet the links need to be further developed and convincingly established. There are a number of basic unanswered questions. First, although elevated harmane concentrations have been observed in ET cases in blood, it is not known whether brain concentrations of this neurotoxin are elevated in ET. Second, current data were derived from a single study of ET cases mainly from a tertiary referral center and they need to be reproduced elsewhere. Third, one small study found elevated blood harmane concentrations in patients with PD [163], which raises the question as to whether elevated blood harmane is specifically linked with ET or if it is merely a more general, global marker of neurological illness. Addressing these basic questions would further delineate the possible 
association between ET and this neurotoxin. Additional studies would also be required to demonstrate that the exposure preceded the disease and was of etiological importance.

\section{Lead}

Human beings may be exposed to organic and inorganic forms of lead through a number of occupational and nonoccupational sources $[164,165]$. In both laboratory animals and human beings, lead exposure may result in an acute or chronic progressive disorder in which action tremor is a prominent feature $[164,166-170]$. Lead exposure produces a destructive cerebellar pathology. Thus, rat pups fed a diet containing $4 \%$ lead acetate demonstrated changes in Purkinje cell morphology [171]. Perinatal exposure to inorganic lead results in degenerative changes in rabbit Purkinje cells [172]. Postmortem examination of humans with chronic organic lead exposure revealed marked destruction of Purkinje cells [169]. This is of particular interest given the observation, noted above, of cerebellar pathology in ET [67, 132-137].

Preliminary evidence suggests that there may be an association between lead exposure and ET. In an initial study at a tertiary referral center in New York [173], blood lead concentrations were measured and a lifetime occupational history was assessed in 100 ET patients and 143 matched controls. Although blood lead concentrations were low in absolute terms, these concentrations were higher in ET patients than in controls (median: 2.7 vs. 2.3 $\mathrm{mg} / \mathrm{dl} ; \mathrm{p}=0.038$ ). In an adjusted logistic regression model, blood lead concentration was associated with ET diagnosis: $\mathrm{OR}=1.19 ; 95 \% \mathrm{CI}=1.03-1.37, \mathrm{p}=0.02$ (that is, each $1 \mathrm{mg} / \mathrm{dl}$ increase in blood lead concentration was associated with a $19 \%$ increased odds of ET). Whether the observed association was due to increased exposure to lead or a difference in lead kinetics/metabolism was not investigated. The prevalence of a history of lifetime occupational lead exposure was similar in ET patients and controls. In a second study [86], the mechanism was explored further. The $\delta$-amino-levulinic acid dehydratase (ALAD) gene codes for ALAD, the principal enzyme involved in lead kinetics. Carriers of the ALAD-2 allele may be more susceptible to lead toxicity. Eighteen (28.6\%) of sixtythree ET cases versus 17 (16.8\%) of 101 controls had an ALAD-2 allele $(\mathrm{OR}=1.98,95 \% \mathrm{CI}=0.9-4.2, \mathrm{p}=0.077)$ and there was an interaction between blood lead concentration and ALAD allele status; the odds of ET were greatly elevated $(\mathrm{OR}=80.3 ; 95 \% \mathrm{CI}=3.1-2,096.4, \mathrm{p}=$ 0.008 ) in individuals with both an ALAD-2 allele and an elevated blood lead concentration. Blood lead concentra- tion was later evaluated in a second study of ET patients at a hospital in Turkey [174]. In that study, the median blood lead concentration was $2.7 \mathrm{mg} / \mathrm{dl}$ in 105 ET cases versus $1.5 \mathrm{mg} / \mathrm{dl}$ in 105 controls $(\mathrm{p}<0.001)$. In a logistic regression model, blood lead concentration was associated with $\mathrm{ET}$ diagnosis: $\mathrm{OR}=4.0 ; 95 \% \mathrm{CI}=2.5-6.4, \mathrm{p}<$ 0.001 (that is, each $1 \mathrm{mg} / \mathrm{dl}$ increase in blood lead concentration was associated with a 4 -fold increased odds of ET). These data replicated those of the previous study in New York.

The possible association of lead exposure with ET is intriguing, yet it needs to be further explored with additional replicate samples, preferably from populationbased studies. Furthermore, bone lead concentration, which is a more valid measure of chronic lead exposure than blood lead, needs to be assessed in ET cases and controls.

\section{Pesticides}

There is a sizable literature on the association between pesticide exposure and PD [104, 107, 108]. As a class of chemicals, pesticides can produce tremor (including action tremor), and organochlorine pesticides (OCPs) are particularly tremorogenic in animals and humans [175178]. The literature on pesticide exposure and ET, however, is limited to few studies [177]. In a study in New York [177], 6 serum OCP concentrations and lifetime occupational histories were assessed in $136 \mathrm{ET}$ cases ascertained from a tertiary referral center and 144 matched control subjects. The 6 serum OCP concentrations were similar in cases and controls. Three (2.2\%) ET cases versus 9 (6.3\%) controls had past occupational exposure to OCPs. This apparent lack of a case-control difference in self-reported exposure to pesticides was confirmed in a second study in Spain of 142 ET patients and 284 controls [179] as well as a third study in Singapore of 79 ET patients and 100 controls, which demonstrated no difference in terms of self-reported pesticide exposure [180]. Exposure histories in each study, however, were brief. These studies represent a beginning and additional studies of ET are needed to assess a wider array of pesticides in more detail, using occupational histories, assessments of residential exposures and biological measures.

\section{Other Exposures}

A small number of studies have examined other potential exposures and their relation to ET. One study at a tertiary referral center in New York examined whether occupational exposures to manganese or organic solvents were associated with ET, but did not find an association 
[181]. This lack of association was confirmed in a second study in Spain of 142 ET patients and 284 controls [179]. In a study in Italy of 27 dental technicians (mean age 49.1 years, no controls), 4 (14.8\%) had mild postural tremor [182], raising the issue of occupational toxin exposure, but these results are difficult to interpret given the high prevalence of postural tremor in the population [183] While the issue of pesticide exposure was discussed above, 2 studies have raised questions about the more general association between agricultural exposures and ET. A small door-to-door survey in Italy that included 28 ET cases and 28 controls noted that the odds for habitual exposure to agricultural chemicals and domestic animals were 2.5 and 2.7 times higher in ET cases, respectively (results not significant) [95]; each of these factors has been reported to be associated with PD [184]. A study of 142 clinic patients and 282 controls in Spain similarly reported that exposure to agricultural work was associated with ET (for agricultural exposure, $\mathrm{OR}=25.4,95 \% \mathrm{CI}=$ 1.43-4.51, $\mathrm{p}=0.002)$; however, reported family history was more strongly associated with ET in that study $(\mathrm{OR}=34.2,95 \% \mathrm{CI}=18.1-64.7, \mathrm{p}<0.001)$ [179]. Additional studies are needed.

\section{Ethanol}

Patients with ET may use ethanol to temporarily lessen the amplitude of their tremor [185, 186], although quantitative studies on relative ethanol consumption in ET cases versus controls have yielded mixed results [187]. The generally accepted causal pathway is that having ET might lead to increased ethanol consumption rather than the converse. Given this model, ethanol would not be considered a risk factor for ET. However, ethanol is a known cerebellar toxin, resulting in profound Purkinje cell loss [188]. Given the emerging links between ET and cerebellar pathology [66], this raises the question as to whether ethanol consumption might be associated with increased risk of incident ET, earlier age of onset of incident ET or more rapid rate of progression of prevalent ET. These issues have not been studied.

\section{Possible Protective Exposures (Cigarettes)}

Numerous studies have demonstrated an association between cigarette smoking and lower risk of PD [189, 190]. Three studies, all in Spain, have examined smoking habits in ET cases compared to controls [179, 191, 192]. In the first of these [179], the proportion of ET clinic patients and controls who smoked was similar, yet the number of cigarette pack years was marginally lower in cases than in controls. The second of these studies was a population- based study in Madrid [191]. In that study, ever smokers were approximately one half as likely to have prevalent ET when compared with never smokers $(\mathrm{OR}=0.58,95 \%$ $\mathrm{CI}=0.40-0.84, \mathrm{p}=0.004)$ and ever smokers in the highest cigarette pack year tertile were one third as likely to have ET when compared with never smokers (adjusted $\mathrm{OR}=0.39,95 \% \mathrm{CI}=0.22-0.69, \mathrm{p}=0.001)$. Finally, in the same study, the association between baseline smoking and incident ET was later examined [192]. Five (6.5\%) of seventy-seven incident ET cases had been smokers at baseline compared with 392 (12.0\%) of 3,271 controls $(\mathrm{p}=0.14)$. Baseline pack years were lower in incident ET cases than controls $(9.2 \pm 17.7$ vs. $15.7 \pm 28.4, \mathrm{p}=0.002)$. In Cox proportional hazards models, highest baseline pack year tertile was associated with lower risk of incident ET; those in the highest baseline pack year tertile were one third as likely to develop incident ET when compared to nonsmokers (adjusted relative risk $=0.29,95 \%$ $\mathrm{CI}=0.09-0.90, \mathrm{p}=0.03)$.

The biological basis for an association between cigarette smoking and possible lower risk of incident ET is not clear. Nicotine has been the focus of this effect for several reasons. First, nicotine is known to protect against the degenerative effects of toxic insults in different experimental systems [193-195]. Nicotine pretreatment consistently reduces the detrimental effects of excitotoxin exposure in cultured cells [193-195], including neurotoxin-induced degeneration of nigral dopamine-containing neurons [196]. Finally, in rats and mice, nicotine can protect against Parkinsonism-inducing neurotoxins like MPTP and methamphetamine [197].

While early epidemiological studies appear to show an inverse dose-dependent association between smoking and the risk of ET, additional prospective studies are needed to further explore the possible protective effects of smoking on risk of ET. Even if such studies were to be confirmatory, given the other adverse health effects of smoking, this activity should not be considered a prudent strategy for reducing the risk of ET.

\section{Caveats}

ET is a common and very widespread disorder whose etiology is likely to be the result of a complex variety of factors. A particular neurotoxin is likely to play an etiological role only in subsets of ET cases, which makes it more difficult to explore and establish such associations when one has no understanding of and has not yet identified those subsets. 
Furthermore, while one scenario is that a neurotoxin/ environmental factor is by itself sufficient to result in a neurological disease, another possibility is that the toxin merely increases the propensity for developing the disorder. For example, a toxin might result in a set of biological changes in the cerebellum (such as Purkinje cell loss), which then increase the exposed individual's sensitivity to the toxic effects of a second event.

\section{Summary}

While ET is widely considered to have a large genetic component [68-74], it is likely that environmental factors contribute to the etiology of ET as well. Such factors are similarly thought to play a substantial role in other progressive, degenerative neurological disorders [102-113].
Work over recent years has explored a number of exposures, including harmane, lead and agricultural exposures/pesticides in preliminary case-control studies, but further work is needed to more fully establish whether these toxins are risk factors for ET. Initial work also suggests that cigarette smoking might be protective of ET.

By some estimates, $2.0 \%$ of the population aged $\geq 40$ years has a nonfamilial form of ET. Despite these high numbers, the environmental correlates for this tremor are just beginning to be explored.

\section{Acknowledgments}

R01 NS039422 from National Institutes of Health (Bethesda, Md., USA).

\section{References}

$\checkmark 1$ Louis ED: Clinical practice: essential tremor. New Engl J Med 2001;345:887-891.

2 Busenbark KL, Nash J, Nash S, Hubble JP, Koller WC: Is essential tremor benign? Neurology 1991;41:1982-1983.

-3 Bain PG, Findley LJ, Thompson PD, Gresty MA, Rothwell JC, Harding AE, Marsden CD: A study of hereditary essential tremor. Brain 1994;117:805-824.

$\checkmark 4$ Louis ED, Barnes L, Albert SM, Cote L, Schneier FR, Pullman SL, Yu Q: Correlates of functional disability in essential tremor. Mov Disord 2001;16:914-920.

5 Koller W, Biary N, Cone S: Disability in essential tremor: effect of treatment. Neurology 1986;36:1001-1004.

6 Rautakorpi I: Essential tremor: an epidemiological, clinical and genetic study; thesis, Turku, 1978

7 Louis ED: Essential tremor. Lancet Neurol 2005;4:100-110.

$\checkmark 8$ Cohen O, Pullman S, Jurewicz E, Watner D, Louis ED: Rest tremor in patients with essential tremor: prevalence, clinical correlates, and electrophysiologic characteristics. Arch Neurol 2003;60:405-410.

-9 Leegwater-Kim J, Louis ED, Pullman SL, Floyd AG, Borden S, Moskowitz CB, Honig LS: Intention tremor of the head in patients with essential tremor. Mov Disord 2006;21: 2001-2005.

10 Deuschl G, Wenzelburger R, Loffler K, Raethjen J, Stolze H: Essential tremor and cerebellar dysfunction clinical and kinematic analysis of intention tremor. Brain 2000;123: $1568-1580$
11 Singer C, Sanchez-Ramos J, Weiner WJ: Gait abnormality in essential tremor. Mov Disord 1994;9:193-196.

12 Stolze H, Petersen G, Raethjen J, Wenzelburger R, Deuschl G: The gait disorder of advanced essential tremor. Brain 2001;124: 2278-2286.

13 Koster B, Deuschl G, Lauk M, Timmer J, Guschlbauer B, Lucking CH: Essential tremor and cerebellar dysfunction: abnormal ballistic movements. J Neurol Neurosurg Psychiatry 2002;73:400-405

$\checkmark 14$ Helmchen C, Hagenow A, Miesner J, Sprenger A, Rambold H, Wenzelburger R, Heide W, Deuschl G: Eye movement abnormalities in essential tremor may indicate cerebellar dysfunction. Brain 2003;126:13191332.

15 Chatterjee A, Jurewicz EC, Applegate LM, Louis ED: Personality in essential tremor: further evidence of non-motor manifestations of the disease. J Neurol Neurosurg Psychiatry 2004;75:958-961.

16 Lorenz D, Schwieger D, Moises H, Deuschl G: Quality of life and personality in essential tremor patients. Mov Disord 2006;21:11141118.

17 Tan EK, Fook-Chong S, Lum SY, Gabriel C Koh KK, Prakash KM, Louis ED: Non-motor manifestations in essential tremor: use of a validated instrument to evaluate a wide spectrum of symptoms. Parkinsonism Relat Disord 2005;11:375-380.
18 Miller KM, Okun MS, Fernandez HF, Jacobson CE 46th, Rodriguez RL, Bowers D: Depression symptoms in movement disorders: comparing Parkinson's disease, dystonia, and essential tremor. Mov Disord 2007;22: 666-672.

19 Louis ED, Benito-Leon J, Bermejo-Pareja F: Self-reported depression and anti-depressant medication use in essential tremor: cross-sectional and prospective analyses in a population-based study. Eur J Neurol 2007; 14:1138-1146.

20 Dogu O, Louis ED, Sevim S, Kaleagasi H, Aral M: Clinical characteristics of essential tremor in mersin, turkey - a populationbased door-to-door study. J Neurol 2005; 252:570-574.

-21 Schneier FR, Barnes LF, Albert SM, Louis ED: Characteristics of social phobia among persons with essential tremor. J Clin Psychiatry 2001;62:367-372.

$>22$ Louis ED: Behavioral symptoms associated with essential tremor. Adv Neurol 2005;96: 284-290.

23 Findley LJ: Expanding clinical dimensions of essential tremor. J Neurol Neurosurg Psychiatry 2004;75:948-949.

24 Lombardi WJ, Woolston DJ, Roberts JW, Gross RE: Cognitive deficits in patients with essential tremor. Neurology 2001;57:785790.

25 Lacritz LH, Dewey R Jr, Giller C, Cullum $\mathrm{CM}$ : Cognitive functioning in individuals with 'benign' essential tremor. J Int Neuropsychol Soc 2002;8:125-129.

-26 Duane DD, Vermilion KJ: Cognitive deficits in patients with essential tremor. Neurology 2002;58:1706; author reply 1706. 
27 Vermilion K, Stone A, Duane D: Cognition and affect in idiopathic essential tremor. Mov Disord 2001;16.

-28 Gasparini M, Bonifati V, Fabrizio E, Fabbrini G, Brusa L, Lenzi GL, Meco G: Frontal lobe dysfunction in essential tremor: a preliminary study. J Neurol 2001;248:399-402.

29 Benito-Leon J, Louis ED, Bermejo-Pareja F: Population-based case-control study of cognitive function in essential tremor. Neurology 2006;66:69-74.

30 Benito-Leon J, Louis ED, Bermejo-Pareja F: Elderly-onset essential tremor is associated with dementia. Neurology 2006;66:15001505 .

31 Bermejo-Pareja F, Louis ED, Benito-Leon J: Risk of incident dementia in essential tremor: a population-based study. Mov Disord 2007.

-32 Benito-Leon J, Louis ED: Essential tremor: emerging views of a common disorder. Nat Clin Pract Neurol 2006;2:666-678.

-33 Dogu O, Sevim S, Camdeviren H, Sasmaz T, Bugdayci R, Aral M, Kaleagasi H, Un S, Louis ED: Prevalence of essential tremor: doorto-door neurologic exams in Mersin province, Turkey. Neurology 2003; 61: 1804-1806.

-34 Louis ED, Ottman R, Hauser WA: How common is the most common adult movement disorder? Estimates of the prevalence of essential tremor throughout the world. Mov Disord 1998;13:5-10.

-35 Rautakorpi I, Takala J, Marttila RJ, Sievers K, Rinne UK: Essential tremor in a finnish population. Acta Neurol Scand 1982;66:58-67.

- 36 Louis ED, Dure LSt, Pullman S: Essential tremor in childhood: a series of nineteen cases. Mov Disord 2001;16:921-923.

- 37 Louis ED, Fernandez-Alvarez E, Dure LS 4th, Frucht S, Ford B: Association between male gender and pediatric essential tremor. Mov Disord 2005;20:904-906.

- 38 Louis ED, Ottman R: Study of possible factors associated with age of onset in essential tremor. Mov Disord 2006;21:1980-1986.

39 Louis ED, Dogu O: Does age of onset in essential tremor have a bimodal distribution? Data from a tertiary referral setting and a population-based study. Neuroepidemiology 2007;29:208-212.

-40 Louis ED, Barnes LF, Ford B, Pullman SL, Yu Q: Ethnic differences in essential tremor. Arch Neurol 2000;57:723-727.

-41 Louis ED, Marder K, Cote L, Pullman S, Ford B, Wilder D, Tang MX, Lantigua R, Gurland B, Mayeux R: Differences in the prevalence of essential tremor among elderly African Americans, Whites, and Hispanics in Northern Manhattan, NY. Arch Neurol 1995;52: 1201-1205.
42 Louis ED, Fried LP, Fitzpatrick AL, Longstreth WT Jr, Newman AB: Regional and racial differences in the prevalence of physician-diagnosed essential tremor in the United States. Mov Disord 2003;18:10351040.

43 Rajput AH, Offord KP, Beard CM, Kurland LT: Essential tremor in Rochester, Minnesota: a 45-year study. J Neurol Neurosurg Psychiatry 1984;47:466-470.

44 Benito-Leon J, Bermejo-Pareja F, Louis ED: Incidence of essential tremor in three elderly populations of central Spain. Neurology 2005;64:1721-1725.

45 Critchley M: Observations of essential (heredofamilial) tremor. Brain 1949;72:113139.

46 Louis ED, Ford B, Barnes LF: Clinical subtypes of essential tremor. Arch Neurol 2000; 57:1194-1198.

47 Louis ED, Jurewicz EC, Watner D: Community-based data on associations of disease duration and age with severity of essential tremor: implications for disease pathophysiology. Mov Disord 2003;18:90-93.

48 Elble RJ, Higgins C, Hughes L: Longitudinal study of essential tremor. Neurology 1992; 42:441-443.

49 Putzke JD, Whaley NR, Baba Y, Wszolek ZK, Uitti RJ: Essential tremor: predictors of disease progression in a clinical cohort. J Neurol Neurosurg Psychiatry 2006;77:12351237.

50 Yahr MD, Orosz D, Purohit DP: Co-occurrence of essential tremor and Parkinson's disease: clinical study of a large kindred with autopsy findings. Parkinsonism Relat Disord 2003;9:225-231.

51 Shahed J, Jankovic J: Exploring the relationship between essential tremor and Parkinson's disease. Parkinsonism Relat Disord 2007;13:67-76.

52 Louis ED, Levy G, Mejia-Santana H, Cote L, Andrews H, Harris J, Waters C, Ford B, Frucht S, Fahn S, Ottman R, Marder K: Risk of action tremor in relatives of tremor-dominant and postural instability gait disorder PD. Neurology 2003;61:931-936.

53 Ondo WG, Lai D: Olfaction testing in patients with tremor-dominant Parkinson's disease: Is this a distinct condition? Mov Disord 2005;20:471-475.

54 Pahwa R, Koller WC: Is there a relationship between Parkinson's disease and essential tremor? Clin Neuropharmacol 1993;16:3035 .

55 Geraghty JJ, Jankovic J, Zetusky WJ: Asso ciation between essential tremor and Parkinson's disease. Ann Neurol 1985;17:329333.

56 Chaudhuri KR, Buxton-Thomas M, Dhawan V, Peng R, Meilak C, Brooks DJ: Long duration asymmetrical postural tremor is likely to predict development of Parkinson's disease and not essential tremor: clinical follow up study of 13 cases. J Neurol Neurosurg Psychiatry 2005;76:115-117.
57 Louis ED, Frucht SJ: Prevalence of essential tremor in patients with Parkinson's disease versus Parkinson-plus syndromes. Mov Disord 2007;22:1402-1407.

58 Benito-Leon J, Bermejo-Pareja F: Risk of incident Parkinson's disease and Parkinsonism in essential tremor: a population-based study. Neurology 2008;70:A191.

-59 Louis ED, Faust PL, Vonsattel JP, Honig LS, Rajput A, Robinson CA, Pahwa R, Lyons KE, Ross GW, Borden S, Moskowitz CB, Lawton A, Hernandez N: Neuropathological changes in essential tremor: 33 cases compared with 21 controls. Brain 2007;130:3297-3307.

60 Louis ED, Honig LS, Vonsattel JP, Maraganore DM, Borden S, Moskowitz CB: Essential tremor associated with focal nonnigral Lewy bodies: a clinicopathologic study. Arch Neurol 2005;62:1004-1007.

61 Ross GW, Cerosimo M, et al: Pathological investigation of essential tremor Neurology 2004;62:A537-A538.

62 Louis ED, Benito-Leon J, Ottman R, Bermejo-Pareja F: A population-based study of mortality in essential tremor. Neurology 2007;69:1982-1989.

63 Hardesty DE, Maraganore DM, Matsumoto JY, Louis ED: Increased risk of head tremor in women with essential tremor: longitudinal data from the Rochester Epidemiology Project. Mov Disord 2004;19:529-533.

64 Louis ED, Ford B, Frucht S: Factors associated with increased risk of head tremor in essential tremor: a community-based study in Northern Manhattan. Mov Disord 2003; 18:432-436.

65 Hubble JP, Busenbark KL, Pahwa R, Lyons K, Koller WC: Clinical expression of essential tremor: effects of gender and age. Mov Disord 1997;12:969-972.

66 Louis ED, Vonsattel JP: The emerging neuropathology of essential tremor. Mov Disord 2007;23:174-182.

67 Louis ED, Vonsattel JP, Honig LS, Ross GW, Lyons KE, Pahwa R: Neuropathologic findings in essential tremor. Neurology 2006;66: $1756-1759$

68 Higgins JJ, Lombardi RQ, Pucilowska J, Jankovic J, Golbe LI, Verhagen L: HS1-BP3 gene variant is common in familial essential tremor. Mov Disord 2006;21:306-309.

-69 Deng H, Le W, Jankovic J: Genetics of essential tremor. Brain 2007;130:1456-1464.

70 Higgins JJ, Pho LT, Nee LE: A gene (ETM) for essential tremor maps to chromosome 2p22p25. Mov Disord 1997;12:859-864.

71 Higgins JJ, Loveless JM, Jankovic J, Patel PI: Evidence that a gene for essential tremor maps to chromosome $2 \mathrm{p}$ in four families. Mov Disord 1998;13:972-977.

72 Kovach MJ, Ruiz J, Kimonis K, Mueed S, Sinha S, Higgins C, Elble S, Elble R, Kimonis VE: Genetic heterogeneity in autosomal dominant essential tremor. Genet Med 2001; 3:197-199. 
-73 Shatunov A, Sambuughin N, Jankovic J, Elble R, Lee HS, Singleton AB, Dagvadorj A, Ji J, Zhang Y, Kimonis VE, Hardy J, Hallett M, Goldfarb LG: Genomewide scans in North American families reveal genetic linkage of essential tremor to a region on chromosome 6p23. Brain 2006;129:2318-2331.

-74 Gulcher JR, Jonsson P, Kong A, Kristjansson K, Frigge ML, Karason A, Einarsdottir IE, Stefansson H, Einarsdottir AS, Sigurthoardottir S, Baldursson S, Bjornsdottir S, Hrafnkelsdottir SM, Jakobsson F, Benedickz J, Stefansson K: Mapping of a familial essential tremor gene, FET1, to chromosome 3q13. Nat Genet 1997;17:84-87.

75 Marshall J: Observations on essential tremor. J Neurol Neurosurg Psychiatry 1962;25: 122-125.

-76 Higgins JJ, Jankovic J, Lombardi RQ, Pucilowska J, Tan EK, Ashizawa T, Ruszczyk MU: Haplotype analysis of the ETM2 locus in familial essential tremor. Neurogenetics 2003;4:185-189.

77 Higgins JJ, Lombardi RQ, Pucilowska J, Jankovic J, Tan EK, Rooney JP: A variant in the HS1-BP3 gene is associated with familial essential tremor. Neurology 2005;64:417421.

78 Higgins JJ, Lombardi RQ, Pucilowska J, Ruszczyk MU: Integrated physical map of the human essential tremor gene region (ETM2) on chromosome 2p24.3-p24.2. Am J Med Genet B Neuropsychiatr Genet 2004; 127:128-130.

-79 Higgins JJ, Lombardi RQ, Tan EK, Jankovic J, Pucilowska J, Rooney JP: Haplotype analysis at the ETM2 locus in a Singaporean sample with familial essential tremor. Clin Genet 2004;66:353-357.

80 Aridon P, Ragonese P, De Fusco M, Salemi G, Casari G, Savettieri G: Further evidence of genetic heterogeneity in familial essential tremor. Parkinsonism Relat Disord 2007.

81 Ma S, Davis TL, Blair MA, Fang JY, Bradford Y, Haines JL, Hedera P: Familial essential tremor with apparent autosomal dominant inheritance: Should we also consider other inheritance modes? Mov Disord 2006;21: 1368-1374.

82 Martinez C, Garcia-Martin E, Alonso-Navarro $\mathrm{H}$, Benito-Leon J, Puertas I, Rubio L, Lopez-Alburquerque T, Agundez JA, Jimenez-Jimenez FJ: Alcohol dehydrogenase 2 genotype and allelic variants are not associated with the risk for essential tremor. Clin Neuropharmacol 2007;30:196-200.

-83 Sazci A, Ergul E, Bayulkem K: Association of the c677t and a1298c polymorphisms of methylenetetrahydrofolate reductase gene in patients with essential tremor in turkey. Mov Disord 2004;19:1472-1476.

84 Martinez C, Garcia-Martin E, Alonso-Navarro $\mathrm{H}$, Benito-Leon J, Puertas I, Rubio L, Lopez-Alburquerque T, Agundez JA, Jimenez-Jimenez FJ: Glutathione-s-transferase $\mathrm{p} 1$ polymorphism and risk for essential tremor. Eur J Neurol 2008;15:234-238.
85 Alonso-Navarro H, Martinez C, GarciaMartin E, Benito-Leon J, Garcia-Ferrer I, Vazquez-Torres P, Puertas I, Lopez-Alburquerque T, Agundez JA, Jimenez-Jimenez FJ: Cyp2c19 polymorphism and risk for essential tremor. Eur Neurol 2006;56:119-123.

86 Louis ED, Applegate L, Graziano JH, Parides M, Slavkovich V, Bhat HK: Interaction between blood lead concentration and $\delta$-amino-levulinic acid dehydratase gene polymorphisms increases the odds of essential tremor. Mov Disord 2005;20:1170-1177.

87 Blair MA, Ma S, Phibbs F, Fang JY, Cooper MK, Davis TL, Hedera P: Reappraisal of the role of the DRD3 gene in essential tremor. Parkinsonism Relat Disord 2008.

88 Deng H, Xie WJ, Le WD, Huang MS, Jankovic J: Genetic analysis of the GABRA1 gene in patients with essential tremor. Neurosci Lett 2006;401:16-19.

89 Xiao Y, Zhang BS: Association of the polymorphism in $\alpha-2$ macroglobulin gene with essential tremor and Parkinson's disease. Zhonghua Yi Xue Yi Chuan Xue Za Zhi 2006; 23:84-85.

90 Agundez JA, Jimenez-Jimenez FJ, Tejeda R, Ledesma MC, Orti-Pareja M, Gasalla T, Molina JA, Ruiz J, Coria F, Duarte J, Vazquez A, Ladero JM, Benitez J: CYP2D6 polymorphism is not associated with essential tremor. Eur Neurol 1997;38:99-104.

91 Louis ED, Ottman R: How familial is familial tremor? The genetic epidemiology of essential tremor. Neurology 1996;46:12001205.

92 Louis ED, Ottman R, Ford B, Pullman S, Martinez M, Fahn S, Hauser WA: The Washington Heights-Inwood genetic study of essential tremor: methodologic issues in essential-tremor research. Neuroepidemiology 1997;16:124-133.

93 Hornabrook RW, Nagurney JT: Essential tremor in Papua, New Guinea. Brain 1976; 99:659-672.

$\$ 94$ Critchley E: Clinical manifestations of essential tremor. J Neurol Neurosurg Psychiatry 1972;35:365-372.

95 Salemi G, Aridon P, Calagna G, Monte M, Savettieri G: Population-based case-control study of essential tremor. Ital J Neurol Sci 1998;19:301-305.

-96 Martinelli P, Gabellini AS, Gulli MR, Lugaresi E: Different clinical features of essential tremor: a 200-patient study. Acta Neurol Scand 1987;75:106-111.

-97 Aiyesimoju AB, Osuntokun BO, Bademosi O, Adeuja AO: Hereditary neurodegenerative disorders in Nigerian Africans. Neurology 1984;34:361-362.

-98 Tanner CM, Goldman SM, Lyons KE, Aston DA, Tetrud JW, Welsh MD, Langston JW, Koller WC: Essential tremor in twins: an assessment of genetic versus environmental determinants of etiology. Neurology 2001; 57:1389-1391.
-99 Lorenz D, Frederiksen H, Moises H, Kopper F, Deuschl G, Christensen K: High concordance for essential tremor in monozygotic twins of old age. Neurology 2004;62: 208-211.

100 Larsson T, Sjogren T: Essential tremor: a clinical and genetic population study. Acta Psychiatr Scand Suppl 1960;36:1-176.

101 Louis ED, Ford B, Frucht S, Barnes LF, XTang M, Ottman R: Risk of tremor and impairment from tremor in relatives of patients with essential tremor: a communitybased family study. Ann Neurol 2001;49: 761-769.

102 Gorell JM, Johnson CC, Rybicki BA, Peterson EL, Kortsha GX, Brown GG, Richardson RJ: Occupational exposure to manganese, copper, lead, iron, mercury and zinc and the risk of Parkinson's disease. Neurotoxicology 1999;20:239-247.

103 Gorell JM, Johnson CC, Rybicki BA, Peterson EL, Kortsha GX, Brown GG, Richardson RJ: Occupational exposures to metals as risk factors for Parkinson's disease. Neurology 1997;48:650-658.

104 Gorell JM, Johnson CC, Rybicki BA, Peterson EL, Richardson RJ: The risk of Parkinson's disease with exposure to pesticides, farming, well water, and rural living. Neurology 1998;50:1346-1350.

105 Rybicki BA, Johnson CC, Uman J, Gorell JM: Parkinson's disease mortality and the industrial use of heavy metals in Michigan. Mov Disord 1993;8:87-92.

106 Racette BA, McGee-Minnich L, Moerlein SM, Mink JW, Videen TO, Perlmutter JS: Welding-related Parkinsonism: clinical features, treatment, and pathophysiology. Neurology 2001;56:8-13.

107 Baldereschi M, Inzitari M, Vanni P, Di Carlo A, Inzitari D: Pesticide exposure might be a strong risk factor for Parkinson's disease. Ann Neurol 2007

108 Dick FD: Parkinson's disease and pesticide exposures. Br Med Bull 2006;79-80:219231.

109 Ritz B, Yu F: Parkinson's disease mortality and pesticide exposure in California 19841994. Int J Epidemiol 2000;29:323-329.

110 Semchuk KM, Love EJ, Lee RG: Parkinson's disease and exposure to agricultural work and pesticide chemicals. Neurology 1992; 42:1328-1335.

111 Shcherbatykh I, Carpenter DO: The role of metals in the etiology of Alzheimer's disease. J Alzheimers Dis 2007;11:191-205.

112 Perl DP: Relationship of aluminum to Alzheimer's disease. Environ Health Perspect 1985;63:149-153.

113 Morahan JM, Yu B, Trent RJ, Pamphlett R: Genetic susceptibility to environmental toxicants in ALS. Am J Med Genet B Neuropsychiatr Genet 2007;144:885-890.

114 Lambert D, Waters CH: Essential tremor. Curr Treat Options Neurol 1999;1:6-13. 
115 McKenna DJ: Plant hallucinogens: springboards for psychotherapeutic drug discovery. Behav Brain Res 1996;73:109-116.

-116 Zetler G, Singbartl G, Schlosser L: Cerebral pharmacokinetics of tremor-producing harmala and iboga alkaloids. Pharmacology 1972;7:237-248.

117 Sakai S: Chemical studies of indole alkaloids. Yakugaku Zasshi 1995;115:351-369.

118 De Meester C: Genotoxic potential of $\beta$ carbolines: a review. Mut Res 1995;339: 139-153.

119 Langston JW, Langston EB, Irwin I: MPTPinduced Parkinsonism in human and nonhuman primates - clinical and experimental aspects. Acta Neurol Scand Suppl 1984; 100:49-54.

120 Smeyne RJ, Jackson-Lewis V: The MPTP model of Parkinson's disease. Brain Res Mol Brain Res 2005;134:57-66.

- 121 Du W, Aloyo VJ, Harvey JA: Harmaline competitively inhibits $\left[{ }^{3} \mathrm{H}\right] \mathrm{MK}-801$ binding to the nmda receptor in rabbit brain. Brain Res 1997;770:26-29.

122 Martin FC, Handforth A: Carbenoxolone and mefloquine suppress tremor in the harmaline mouse model of essential tremor. Mov Disord 2006;21:1641-1649.

123 Martin FC, Thu Le A, Handforth A: Harmaline-induced tremor as a potential preclinical screening method for essential tremor medications. Mov Disord 2005;20: 298-305.

124 Krahl SE, Martin FC, Handforth A: Vagus nerve stimulation inhibits harmaline-induced tremor. Brain Res 2004;1011:135138.

125 Handforth A, Krahl SE: Suppression of harmaline-induced tremor in rats by vagus nerve stimulation. Mov Disord 2001;16:8488.

126 Sinton CM, Krosser BI, Walton KD, Llinas RR: The effectiveness of different isomers of octanol as blockers of harmaline-induced tremor. Pflugers Arch 1989;414:3136.

127 Milner TE, Cadoret G, Lessard L, Smith AM: EMG analysis of harmaline-induced tremor in normal and three strains of mutant mice with Purkinje cell degeneration and the role of the inferior olive. J Neurophysiol 1995;73:2568-2577.

-128 Trouvin JH, Jacqmin P, Rouch C, Lesne M, Jacquot C: Benzodiazepine receptors are involved in tabernanthine-induced tremor: in vitro and in vivo evidence. Eur J Pharmacol 1987;140:303-309.

-129 Fuentes JA, Longo VG: An investigation on the central effects of harmine, harmaline and related $\beta$-carbolines. Neuropharmacology 1971;10:15-23.

- 130 Cross AJ, Misra A, Sandilands A, Taylor MJ, Green AR: Effect of chlormethiazole, dizocilpine and pentobarbital on harmaline-induced increase of cerebellar cyclic GMP and tremor. Psychopharmacology (Berl) 1993;111:96-98.
131 Rappaport MS, Gentry RT, Schneider DR, Dole VP: Ethanol effects on harmaline-induced tremor and increase of cerebellar cyclic GMP. Life Sci 1984;34:49-56.

132 Louis ED, Shungu DC, Chan S, Mao X, Jurewicz EC, Watner D: Metabolic abnormality in the cerebellum in patients with essential tremor: a proton magnetic resonance spectroscopic imaging study. Neurosci Lett 2002;333:17-20.

133 Louis ED, Shungu DC, Mao X, Chan S, Jurewicz EC: Cerebellar metabolic symmetry in essential tremor studied with ${ }^{1} \mathrm{H}$ magnetic resonance spectroscopic imaging: implications for disease pathology. Mov Disord 2004;19:672-677.

$>134$ Louis ED, Vonsattel JP, Honig LS, Lawton A, Moskowitz C, Ford B, Frucht S: Essential tremor associated with pathologic changes in the cerebellum. Arch Neurol 2006;63: 1189-1193.

135 Pagan FL, Butman JA, Dambrosia JM, Hallett M: Evaluation of essential tremor with multi-voxel magnetic resonance spectroscopy. Neurology 2003;60:1344-1347.

136 Shill H, Sabbagh M, Connor D, Caviness J, Beach T: Pathological changes in prospectively-ascertained essential tremor subjects. Neurology 2007;68.

137 Axelrad JE LE, Honig LS, Flores I, Ross GW, Pahwa R, Lyons KE, Faust PL, Vonsattel JP: Reduced Purkinje cell number in essential tremor: a postmortem study. Arch Neurol 2008;65:101-107.

138 O’Hearn E, Long DB, Molliver ME: Ibogaine induces glial activation in parasagittal zones of the cerebellum. Neuroreport 1993;4:299-302.

139 O’Hearn E, Molliver ME: Degeneration of purkinje cells in parasagittal zones of the cerebellar vermis after treatment with ibogaine or harmaline. Neuroscience 1993;55: 303-310.

140 O'Hearn E, Molliver ME: The olivocerebellar projection mediates ibogaine-induced degeneration of purkinje cells: a model of indirect, trans-synaptic excitotoxicity. J Neurosci 1997;17:8828-8841.

141 Robertson HA: Harmaline-induced tremor: the benzodiazepine receptor as a site of action. Eur J Pharmacol 1980;67:129-132.

142 Lewin L: Untersuchungen über Banisteria caapi sp. Arch Exp Pathol Pharmacol 1928; 129:133-149.

143 Pennes HH, Hoch PH: Psychotomimetics, clinical and theoretical considerations: harmine, win-2299 and nalline. Am J Psychiatry 1957;113:887-892.

144 Moncrieff J: Determination of pharmacological levels of harmane, harmine and harmaline in mammalian brain tissue, cerebrospinal fluid and plasma by high-performance liquid chromatography with fluorimetric detection. J Chromatogr 1989;496:269-278.
145 Anderson NJ, Tyacke RJ, Husbands SM, Nutt DJ, Hudson AL, Robinson ES: In vitro and ex vivo distribution of $\left[{ }^{3} \mathrm{H}\right]$ harmane, an endogenous $\beta$-carboline, in rat brain. Neuropharmacology 2006;50:269-276.

146 Matsubara K, Collins MA, Akane A, Ikebuchi J, Neafsey EJ, Kagawa M, Shiono H: Potential bioactivated neurotoxicants, $\mathrm{n}$ methylated $\beta$-carbolinium ions, are present in human brain. Brain Res 1993;610:9096.

147 Gearhart DA, Collins MA, Lee JM, Neafsey EJ: Increased $\beta$-carboline $9 \mathrm{~N}$-methyltransferase activity in the frontal cortex in Parkinson's disease. Neurobiol Dis 2000;7: 201-211.

148 Wakabayashi K, Totsuka Y, Fukutome K, Oguri A, Ushiyama H, Sugimura T: Human exposure to mutagenic/carcinogenic heterocyclic amines and comutagenic $\beta$-carbolines. Mutat Res 1997;376:253-259.

149 Pfau W, Skog K: Exposure to $\beta$-carbolines norharman and harman. J Chromatogr B Analyt Technol Biomed Life Sci 2004;802: 115-126.

150 Gross GA, Turesky RJ, Fay LB, Stillwell WG, Skipper PL, Tannenbaum SR: Heterocyclic aromatic amine formation in grilled bacon, beef and fish and in grill scrapings. Carcinogenesis 1993;14:2313-2318.

151 Skog K, Solyakov A, Arvidsson P, Jagerstad M: Analysis of nonpolar heterocyclic amines in cooked foods and meat extracts using gas chromatography-mass spectrometry. J Chromatogr A 1998;803:227-233.

152 Skog K: Cooking procedures and food mutagens: a literature review. Food Chem Toxicol 1993;31:655-675.

153 Layton DW, Bogen KT, Knize MG, Hatch FT, Johnson VM, Felton JS: Cancer risk of heterocyclic amines in cooked foods: an analysis and implications for research. Carcinogenesis 1995; 16:39-52.

154 Sinha R, Rothman N, Salmon CP, Knize MG, Brown ED, Swanson CA, Rhodes D, Rossi S, Felton JS, Levander OA: Heterocyclic amine content in beef cooked by different methods to varying degrees of doneness and gravy made from meat drippings. Food Chem Toxicol 1998;36:279-287.

- 155 Sinha R, Knize MG, Salmon CP, Brown ED, Rhodes D, Felton JS, Levander OA, Rothman N: Heterocyclic amine content of pork products cooked by different methods and to varying degrees of doneness. Food Chem Toxicol 1998;36:289-297.

156 Herraiz T: Relative exposure to $\beta$-carbolines norharman and harman from foods and tobacco smoke. Food Addit Contam 2004:21:1041-1050.

157 Louis ED, Zheng W, Jurewicz EC, Watner D, Chen J, Factor-Litvak P, Parides M: Elevation of blood $\beta$-carboline alkaloids in essential tremor. Neurology 2002;59:19401944. 
158 Louis ED, Jiang W, Pellegrino KM, Rios E, Factor-Litvak P, Henchcliffe C, Zheng W: Elevated blood harmane (1-methyl-9Hpyrido[3,4-B]indole) concentrations in essential tremor. Neurotoxicology 2008;29: 294-300.

159 Louis ED, Zheng W, Mao X, Shungu DC: Blood harmane is correlated with cerebellar metabolism in essential tremor: a pilot study. Neurology 2007;69:515-520.

160 Louis ED, Zheng W, Applegate L, Shi L, Factor-Litvak P: Blood harmane concentrations and dietary protein consumption in essential tremor. Neurology 2005;65: 391-396.

-161 Willett WC, Sampson L, Stampfer MJ, Rosner B, Bain C, Witschi J, Hennekens CH, Speizer FE: Reproducibility and validity of a semiquantitative food frequency questionnaire. Am J Epidemiol 1985;122:5165.

162 Louis ED, Keating GA, Bogen KT, Rios E, Pellegrino KM, Factor-Litvak P: Dietary epidemiology of essential tremor: meat consumption and meat cooking practices. Neuroepidemiology 2008;30:161-166.

-163 Kuhn W, Muller T, Grosse H, Rommelspacher H: Plasma harman and norharman in Parkinson's disease. J Neural Transm Suppl 1995;46:291-295.

-164 Coulehan JL, Hirsch W, Brillman J, Sanandria J, Welty TK, Colaiaco P, Koros A, Lober A: Gasoline sniffing and lead toxicity in Navajo adolescents. Pediatrics 1983;71: 113-117.

165 Winegar DA, Levy BS, Andrews JS Jr, Landrigan PJ, Scruton WH, Krause MJ: Chronic occupational exposure to lead: an evaluation of the health of smelter workers. J Occup Med 1977;19:603-606.

- 166 Booze RM, Mactutus CF, Annau Z, Tilson HA: Neonatal triethyl lead neurotoxicity in rat pups: initial behavioral observations and quantification. Neurobehav Toxicol Teratol 1983;5:367-375.

167 Goldings AS, Stewart RM: Organic lead encephalopathy: behavioral change and movement disorder following gasoline inhalation. J Clin Psychiatry 1982;43:70-72.

168 Seshia SS, Rjani KR, Boeckx RL, Chow PN: The neurological manifestations of chronic inhalation of leaded gasoline. Dev Med Child Neurol 1978;20:323-334.

-169 Valpey R, Sumi SM, Copass MK, Goble GJ: Acute and chronic progressive encephalopathy due to gasoline sniffing. Neurology 1978;28:507-510.

-170 Young RS, Grzyb SE, Crismon L: Recurrent cerebellar dysfunction as related to chronic gasoline sniffing in an adolescent girl: lead poisoning from 'leaded' gasoline as an attendent complication. Clin Pediatr (Phila) 1977;16:706-708.
171 McConnell P, Berry M: The effects of postnatal lead exposure on purkinje cell dendritic development in the rat. Neuropathol Appl Neurobiol 1979;5:115-132.

172 Walsh TJ, Tilson HA: Neurobehavioral toxicology of the organoleads. Neurotoxicology 1984;5:67-86.

173 Louis ED, Jurewicz EC, Applegate L, Factor-Litvak P, Parides M, Andrews L, Slavkovich V, Graziano JH, Carroll S, Todd A: Association between essential tremor and blood lead concentration. Environ Health Perspect 2003;111:1707-1711.

-174 Dogu O, Louis ED, Tamer L, UnalO, Yilmaz A, Kaleagasi H: Elevated blood lead concentrations in essential tremor: a case-control study in Mersin, Turkey. Environ Health Perspect 2007;115:1564-1568.

175 Taylor JR: Neurological manifestations in humans exposed to chlordecone and follow-up results. Neurotoxicology 1982;3:916.

176 Taylor JR, Selhorst JB, Houff SA, Martinez AJ: Chlordecone intoxication in man. I. Clinical observations. Neurology 1978;28: 626-630.

177 Louis ED, Factor-Litvak P, Parides M, Andrews L, Santella RM, Wolff MS: Organochlorine pesticide exposure in essential tremor: a case-control study using biological and occupational exposure assessments. Neurotoxicology 2006;27:579-586.

178 Cannon SB, Veazey JM Jr, Jackson RS, Burse VW, Hayes C, Straub WE, Landrigan PJ, Liddle JA: Epidemic kepone poisoning in chemical workers. Am J Epidemiol 1978; 107:529-537.

179 Jiménez-Jiménez FJ dT-HM, Alonso-Navarro H, Ayuso-Peralta L, Arévalo-Serrano J, Ballesteros-Barranco A, Puertas I, Jabbour-Wadih T, Barcenilla B: Environmental risk factors for essential tremor. Eur Neurol 2007;58:106-113.

180 Prakash KM, Fook-Choong S, Yuen Y, Tan EK: Exploring the relationship between caffeine intake and essential tremor. J Neurol Sci 2006;251:98-101.

-181 Louis ED, Applegate LM, Factor-Litvak P, Parides MK, Andrews L: Essential tremor: occupational exposures to manganese and organic solvents. Neurology 2004;63:21622164.

-182 Fabrizio E, Vanacore N, Valente M, Rubino A, Meco G: High prevalence of extrapyramidal signs and symptoms in a group of Italian dental technicians. BMC Neurol 2007;7:24.

183 Louis ED, Ford B, Pullman S, Baron K: How normal is 'normal'? Mild tremor in a multiethnic cohort of normal subjects. Arch Neurol 1998;55:222-227.
184 Ben-Shlomo Y: How far are we in understanding the cause of parkinson's disease? J Neurol Neurosurg Psychiatry 1996;61:416.

185 Rautakorpi I, Marttila RJ, Rinne UK: Alcohol consumption of patients with essential tremor. Acta Neurol Scand 1983;68:177179.

186 Nasrallah HA, Schroeder D, Petty F: Alcoholism secondary to essential tremor. J Clin Psychiatry 1982;43:163-164.

187 Louis ED, Jurewicz EC, Applegate L, Luchsinger JA, Factor-Litvak P, Parides M: Semiquantitative study of current coffee, caffeine, and ethanol intake in essential tremor cases and controls. Mov Disord 2004;19:499-504.

188 Torvik A, Torp S: The prevalence of alcoholic cerebellar atrophy: a morphometric and histological study of an autopsy material. J Neurol Sci 1986;75:43-51.

189 Gorell JM, Rybicki BA, Johnson CC, Peterson EL: Smoking and parkinson's disease: a dose-response relationship. Neurology 1999;52:115-119.

190 Ritz B, Ascherio A, Checkoway H, Marder KS, Nelson LM, Rocca WA, Ross GW, Strickland D, Van Den Eeden SK, Gorell J: Pooled analysis of tobacco use and risk of Parkinson disease. Arch Neurol 2007;64: 990-997.

191 Benito-Leon J, Louis ED, Permejo-Pareja F: Population-based case-control study of cigarette smoking and essential tremor. Mov Disord 2008;23:246-252.

192 Louis ED, Benito-Leon J, Permejo-Pareja F: Population-based prospective study of cigarette smoking and risk of incident essential tremor. Neurology 2008;70:1682-1687.

193 Mudo G, Belluardo N, Fuxe K: Nicotinic receptor agonists as neuroprotective/neurotrophic drugs: progress in molecular mechanisms. J Neural Transm 2007;114: 135-147.

194 Meissner W, Hill MP, Tison F, Gross CE, Bezard E: Neuroprotective strategies for Parkinson's disease: conceptual limits of animal models and clinical trials. Trends Pharmacol Sci 2004;25:249-253.

195 Zanardi A, Leo G, Biagini G, Zoli M: Nicotine and neurodegeneration in ageing. Toxicol Lett 2002;127:207-215.

196 Jeyarasasingam G, Tompkins L, Quik M: Stimulation of non- $\alpha 7$ nicotinic receptors partially protects dopaminergic neurons from 1-methyl-4-phenylpyridinium-induced toxicity in culture. Neuroscience 2002;109:275-285.

197 Maggio R, Riva M, Vaglini F, Fornai F, Molteni R, Armogida M, Racagni G, Corsini GU: Nicotine prevents experimental parkinsonism in rodents and induces striatal increase of neurotrophic factors. J Neurochem 1998;71:2439-2446. 